UDC 316:379.8

Gohar MKOYAN

\title{
THE ROLE AND MEANING OF THE FREE TIME IN CONTEXT OF FORMATION OF SOCIO-CULTURAL VALUES IN MODERN ARMENIAN SOCIETY
}

\begin{abstract}
The article considers the problem of a culture of free time as a factor in the formation of modern society that has entered the era of globalization - with the respective opportunities for a variety of leisure activities and, at the same time, it may assume problematic situations for the person related to the effective use of leisure potential for the development of leisure culture of the person.

The aim of this study was to examine the role and free time value in the formation of social and cultural values in our society between two generations - today's youth (18 to 30 years) and the older generation ( 56 to 66 years), to identify the particular preferences in the environment of two generations in the field of leisure, to provide a comparative analysis and assessment of the data. The author had the task of considering the organization of free time as scientific and social problems, its effective implementation representatives of the two age groups, the disclosure of the content of free time of concept of culture. The research has used quantitative and qualitative methods of sociological research - unstructured data included observations, expert study using unstructured in-depth interviews, the survey (questionnaires), interviews by stratificat sampling in compliance with the proportions of the population structure by sex and age.

In the analysis, we stopped on such objective indicators of the quality of free time as a variety of leisure activities, especially the preferences of two generations in leisure activities (the prevalence of reading, resort to information and communication technologies, the frequency of visits to entertainment, cultural and leisure facilities, etc.).

The article explains the idea that free time acquires its true value when it is directed to the full development of the person and the acquisition of their socio-cultural values, as well as with the growth of free time, the role of self-development and reduced the share of inactive leisure.
\end{abstract}

Keywords: culture of spare time, generation, individual, values, society, activity, leisure.

Free time takes a significant place in the socio-cultural life of a society. Nowadays, connected with the fact that people gain more free time due to the technical household appliances, due to the growth of mobility of people during holidays, the meaning of free time and the problem of organizing leisure have become especially actual.

It should be mentioned that the attention of scholars to this issue has been mentioned in 
all periods of development of theoretical knowledge- from the ancient world up to nowadays.

In the works of ancient philosophers (Socrates, Plato, Aristotle) we come across with the same ideas and thoughts about free time. The investigation of historical experience and the cultural heritage of antiquity show that one of the most important distinguishing features of antiquity as civilization was the perception of leisure time, which was widely accepted among Greeks and Romans. Leisure time meant a period of time free of any kind of materially-essential employment, as an important characteristic of civil condition. Free time and leisure were studied along with freedom, social state and self-development.

Thus in Plato's pedagogical theory free time was connected with cognitive activity. According to Plato "Cognition must bring joy, and the word "school" itself translated from Latin means "leisure" and leisure is always connected with something pleasant. That is why it is important to make the cognitive process pleasant and useful in all relations (Tadevosyan, 2011, p. 13).

A thorough scientific philosophical, scientific- social research of a number of issues referring to free time and leisure in foreign and Soviet science is connected with such names as M. Weber, G. Spenser, P. Sorokin, V.A. Gross, S.N. Ikonnikova, M. Kaplan, B.G. Mosalev, A.S. Orlov, V.D. Patrushev, E.V. Sokolov, G.G. Boloshenko, V.A. Volovik and others.

Today the term "free time" and "leisure" are often used as synonyms. We can find various explanations of free time 1) as a time period freed or "cleaned" of expenses, 2) as a period of time beyond the necessary work, which is devoted to rest, pastime and development of individuality, 3) as a period of "self-evaluation" time, 4) as a period of time during which a person has the opportunity of free action (Osipov, 2008, p. 443).

As sociologist Kravchenko has it: "Leisure is that period of time which a person spares as he/she wishes. Leisure is an activity which is done for the sake of one's own pleasure, fun, self-development or reaching other goals by one's own choice, and not for the sake of material need" (Kravchenko, 2011, p. 30).

British sociologist Bauman mentions that the meaning of leisure strengthens also the special meaning of information as the basic economical resource of post-industrial society. The main source of growth becomes the particular potential of a person who produces information that is why researchers cross out the special meaning of humanitarian factors in modern society (Bauman, 2002, p. 30).

E.V. Sokolov mentions in his research, that free time is not considered as an "empty space" of a life period. It is the "resource" which is gained by special efforts, possesses specific qualities and can be used with more or less efficiency depending on the qualities and the size of potential of a society and an individual (Sokolov, 1981, p. 40).

It should be mentioned that leisure activity is considered as a process of creation, dissemination and multiplication of cultural values. E.I. Tyurina writes "Badly organized leisure, unplanned free time serves the sources of "anticulture" (Tyurina, 2012, p. 8). In this case the notion of free time culture acquires a special meaning. 
The term "free time culture" points to a definite level of time usage, including not only size and structure, but also content and nature- knowledge, values, norms, examples of life-activities. Free time is not only a private, but also a social value and the attitudes towards leisure are considered to be important indicators of an individual's culture (Ikonnikova, 1985, p. 32). According to V.Y. Surtaeva the culture of leisure is the extent of realization of an individual's socio-cultural potential in terms of leisure time. It is also the extent of gained experience of regulating leisure time, the ability of an individual to take part in socially important types of leisure (Surtaev, 1998, p. 28).

The issue of free time, connected with the efforts of a society to organize leisure, should be accepted as an actual one in conditions of modern society facing the era of globalization. Many important issues and growing interest towards the above mentioned problems brought us to investigate the given sphere, to elaborate corresponding methods, to do comparative analysis, to describe and evaluate the results.

Sociological researches were held during the last four years. One of them was qualitative (from March to May 2015) and the other three were quantitative, held from 2013 up to 2016.

The aim of our research was to study the transformations of socio-cultural values in Armenian modern society. The objects of our research were two age groups, today's youth (from 18-30 years old) and the representatives of older generation (from 55 to 66 years old) who actively take part in the political and public life of the country. The objects of our research were valuable priorities, continuity and essential changes of values of two generations in modern society of Armenia.

A pilotage was held during the first stage of research which resulted in specifying and eventually working out the instruments of our upcoming sociological research. During the second stage we gathered information using the methods of qualitative and quantitative analysis. In first quantitative research (2013) took part198 citizens of Yerevan, and in the second research (2014) the students of National Polytechnic University Of Armenia, and the students of Armenian state Pedagogical University after Kh. Abovyan with 205 students. The participants of survey were students from 18 to 30 years old and the representatives of older generation, ex-students of the above mentioned universities from 55 to 66 years old. We used the method of formalized interview (standardizing), questionnaire. Statistical presentability was provided by giving each participant the chance to be chosen. The third qualitative research was held using the method of expert survey between 56 experts, with the help of unstructured in-depth interview method (2015). The choice of experts was made taking into consideration the fact of belonging to various social institutions (state, non-state, private, and public) and independent experts. The type of retrieval was goal-directed, and the criteria of the choice of experts were experience, the level of being educated, the sphere of involvement, the degree of perception from the point of view of society and etc.

In the present article the results of the fourth research are represented (2016), which was held among two different age groups of our population. The general totality of retrieval of inhabitants of Yerevan, 33.5\% are above 
mentioned age groups. During the three months of research about 250 inhabitants were involved, who all were citizens of Yerevan (table1).

Table 1. Selective Totality of Participants by Age and Gender (person, \%)

\begin{tabular}{|c|c|c|c|c|c|c|c|}
\hline № & Age structure of Participants & & Incluc & & & Incluc & $(\%)$ \\
\hline \multirow[t]{2}{*}{1.} & \multirow{2}{*}{$\begin{array}{l}\text { Young people from } 18 \text { to } 30 \\
\text { years old }\end{array}$} & \multirow[b]{2}{*}{143} & Male & Female & \multirow[t]{2}{*}{100,0} & Male & Female \\
\hline & & & 65 & 78 & & 45.2 & 54.7 \\
\hline 2. & $\begin{array}{l}\text { Older generation from } 55 \text { to } \\
66 \text { years old }\end{array}$ & 107 & 61 & 46 & 100,0 & 57.2 & 42.5 \\
\hline
\end{tabular}

$52.2 \%$ of respondents were representatives of youth from 18 to 30 years old $(45.3 \%$ were male and $54.7 \%$ were female) $42.7 \%$ of respondents were representatives of older generation from 55 to 66 years old $(57.5 \%$ were male and $42.5 \%$ were female). We used the method of quantitative research- survey (questionnaire) interviewing taking into consideration gender and age. The questionnaire included 58 questions from which 14 revealed the interests of respondents about the culture of organizing free time. Besides, respondents were given a number of questions which required logical thinking, finding out the meanings, points of view and evaluation in terms of the issue under study. Selective totality was calculated by the principle of proportionality from the number of overall population. After that we implemented the principle of random choice. The general totality was divided into age groups using the method of stratified choice. Unproportionality was examined taking into account age, education and gender. In the process of research were included all age categories - young people as well as older generation, which enabled us to get trusty data in order to hold objective comparative analysis with the aim of bringing out continuity or changing valuable orientations of two generations under study. We carried on a calculation of selection extent for the provision of presentability. We also defined the interval confidence as well as the possibility of incorrectness up to $5.0 \%$. In the third stage we analyzed all the results and data of above mentioned researches. As a result of sociological research we found out that the representatives of these two groups, despite their occupancy, try to find free time and to find ways to use it rationally. While answering the question "How much free time do you usually have?" $5.6 \%$ of young people answered "quite much", $24.5 \%$ "enough", $32.8 \%$ "have no free time", 3.96\% "very little free time" and 3.7\% "not much". The representatives of older generation answered the same questions the following way "quite much", 13.0\% "enough", $12.7 \%$ "have no free time", $25.5 \%$ "very little free time" and $21.8 \%$ "not much" $23.6 \%$. The results of our research show that this kind of 
percentage is due to the fact that very often young people do not perceive the process of education as a free time and do not identify the time spent with their fellow-students as a leisure time. As the famous philosopher I.T. Frolov mentions free time also includes education and self-education, contact with culture (reading, attending theatre, museum, cinema and etc.) social-political activity, scientifictechnical amateur creations, artistic-aesthetic creativity, dealing with children, even anticultural activities (Frolov, 1991, pp. 400-401).

The answers of respondents "have no free time" points out the fact that in our society free time is usually associated with that period of time when a person does nothing or rests. As an answer to this particular question $21.8 \%$ of respondents of older generation (compared to young people 3.96\%. 6 times less) answered that they have very little free time. It can be explained by the fact that a person of that particular age bears a rational character, a person starts to realize that for objective and subjective reasons must refuse definite roles and purposefully strive to achieve all his/her goals, thus exhausting himself/herself as a sexual, parental and working subject. As a rule a person at this age tries to stay in his/her vital and occupational positions.

The results of the survey formed as "How do you prefer to spend your leisure time" showed that the two age groups gave their preferences to family $(30.2 \%$ of young people, $49.1 \%$ of older generation), as well as to friends $(54.7 \%$ of young people, $43.6 \%$ of older generation) and only after that to colleagues $(9.4 \%$ of young people, $3.6 \%$ of older generation) and finally to relatives $(5.7 \%$ of young people, $3.7 \%$ of older generation). De- spite some percentage variations, we can state that in our society family and friendship are greatly valued. There were also coinciding opinions in the sphere of culture and literature, issues referring to cloth styles while attending cultural places. In all cases the preferences were given to classical styles. Undoubtedly, it represents the continuity of generations, handing over cultural traditions and values of formed orientations and mechanisms from generation to generation.

In the list of fun activities $35.2 \%$ of representatives of youth prefer TV programs, watching videos and various programs on Internet. $15.0 \%$ attend disco clubs and cafes, $14.0 \%$ go in for sports and take part in sport competitions. Lower percents were as follows-9.5\%attended cinemas, concerts and $7.5 \%$ read literature. And the results of our survey among people of older generation revealed the following data. In the column "do not attend" on the first place are going in for sports and taking part in sport competitions $(76.3 \%)$, on the second place is attending disco clubs and cafes $(65.5 \%)$, on the third place is attending restaurants $(41.8 \%)$, on the forth place are going to the cinema, theatre and concerts $(36.4 \%)$, and TV programs, watching videos and Internet $(24.5 \%)$ are only on the fifth place. Most of older people prefer to stay at home and maintain household problems, look after domestic animals, and attend libraries and order books. Our observation revealed that $65.0 \%$ of respondents among two generations due to the lack of money can afford only particular kinds of free time. It should be mentioned that connected with the socioeconomic state of the country, today we have such kinds of leisure activities as shopping, fast driving and etc. First of all the given situ- 
ation affects such a socio-demographic group as youth.

Love towards book, the culture of reading play an important role in our society. However, we can state that lately we are having a decline in interests towards reading among young people compared to representatives of older generation. (Table 2, 3) We can conclude that this kind of results can be conditioned by the fact that compared to older generation; young people do not have the culture of everyday reading. $35.8 \%$ of young people and $23.6 \%$ of older generation read science books or press (including electronic, on Internet). The difference in the percentage referring to electronic literature can be explained by the fact that many representatives of older generation are not able or partially are not able to use a computer or Internet. We come to assume that today on the one hand Internet has its advantages (a large amount of stored information, as well as the speed of its transmission) and on the other hand negative impact on national traditions - relationships in a family, discussions, friendship relations, the desire to discuss a recently read book, to pass it to each other (because it is available on Internet and there is a speedy E-mail).

Table 2. Interests towards Reading among Young People at the Age of 18-30 (\%)

\begin{tabular}{|c|c|c|c|c|c|c|c|}
\hline \multirow[b]{2}{*}{ № } & \multirow[b]{2}{*}{ Activity } & \multicolumn{6}{|c|}{ Amount } \\
\hline & & $\begin{array}{l}\text { Every } \\
\text { day }\end{array}$ & $\begin{array}{c}\text { Several } \\
\text { times } \\
\text { in a } \\
\text { week }\end{array}$ & $\begin{array}{l}\text { Several } \\
\text { times in } \\
\text { a month }\end{array}$ & $\begin{array}{c}\text { Several } \\
\text { times } \\
\text { in a } \\
\text { year }\end{array}$ & Seldom & $\begin{array}{l}\text { Do not } \\
\text { attend/ } \\
\text { do not } \\
\text { read/ do } \\
\text { not buy }\end{array}$ \\
\hline 1. & $\begin{array}{l}\text { You read fiction (including electron- } \\
\text { ic on Internet) }\end{array}$ & 5.7 & 20.8 & 24.5 & - & 30.2 & 18.8 \\
\hline 2. & $\begin{array}{l}\text { You read science books or press (in- } \\
\text { cluding electronic on Internet) }\end{array}$ & 22,6 & 18.9 & 15.1 & 13.2 & 15.1 & 15.1 \\
\hline 3. & $\begin{array}{l}\text { You read entertaining magazines and } \\
\text { journals (including electronic on In- } \\
\text { ternet) }\end{array}$ & 35.8 & 15.1 & 17.0 & 5.7 & 17.0 & 9.4 \\
\hline 4. & $\begin{array}{l}\text { You read socio-political newspapers } \\
\text { and journals, analytical articles (in- } \\
\text { cluding electronic on Internet) }\end{array}$ & 24.5 & 11.3 & 15.1 & 13.2 & 22.6 & 11.3 \\
\hline
\end{tabular}


Table 3. Interests towards Reading among Armenian Citizens at the Age of 56-66. (\%)

\begin{tabular}{|c|c|c|c|c|c|c|c|}
\hline \multirow[b]{2}{*}{ № } & \multirow[b]{2}{*}{ Activity } & \multicolumn{6}{|c|}{ Amount } \\
\hline & & $\begin{array}{c}\text { Every } \\
\text { day }\end{array}$ & $\begin{array}{l}\text { Several } \\
\text { times in } \\
\text { a week }\end{array}$ & $\begin{array}{l}\text { Several } \\
\text { times in } \\
\text { a month }\end{array}$ & $\begin{array}{c}\text { Several } \\
\text { times } \\
\text { in a } \\
\text { year }\end{array}$ & Seldom & $\begin{array}{l}\text { Do not } \\
\text { attend/ } \\
\text { do not } \\
\text { read/ } \\
\text { do not } \\
\text { buy }\end{array}$ \\
\hline 1. & $\begin{array}{l}\text { You read fiction (including electronic } \\
\text { on Internet) }\end{array}$ & 20.1 & 21.8 & 16.4 & 12.7 & 14.5 & 14.5 \\
\hline 2. & $\begin{array}{l}\text { You read science books or press (in- } \\
\text { cluding electronic on Internet) }\end{array}$ & 23.6 & 18.2 & 14.5 & 11.0 & 10.9 & 21.8 \\
\hline 3. & $\begin{array}{l}\text { You read entertaining magazines and } \\
\text { journals (including electronic on In- } \\
\text { ternet) }\end{array}$ & 23.6 & 10.9 & 21.8 & 10.9 & 29.2 & 3.6 \\
\hline 4. & $\begin{array}{l}\text { You read socio-political newspapers } \\
\text { and journals, analytical articles (in- } \\
\text { cluding electronic on Internet) }\end{array}$ & 36.4 & 10.8 & 9.1 & 5.5 & 25.5 & 12.7 \\
\hline
\end{tabular}

Analyzing the peculiarities, the role and the meaning of free time in formation of socio-cultural values in our society among two generations- today's youth (from 18 to 30years old) and the representatives of older generation (from 56 to 66 years old) we arrive at the following conclusions:

This research is actual both from theoretical and practical point of view, it gives the opportunity to understand thoroughly the phenomenon of leisure, free time. We should accept that it is not only practical source of opportunities, but also a special range of values. The analysis of answers shows that free time today becomes a problem for young people as well as for older generation. Its subjective quality is almost the same for both age groups, but objective quality of their free time differs. Most free time activities even those which are free of financial expenses, seldom attract older people. Their free time passes less interesting, and as a matter of fact they do not try to change this situation, they rarely think about its meaning and do not express any unsatisfication. Besides, their free time, though monotonous, differs by its high intellectuality (the level of interest towards reading, attending cultural-leisure institutions and etc.).

It can be mentioned that during the last few years Armenian youth, while choosing the types of free time, gives the advantage to the orientations of values of pastimes (hedonism), success (achievements) and novelty (stimulations) without counting the deep meaning of values, traditions and conformities. Young people spend their free time with friends. They prefer to attend cultural events concerts, exhibitions, disco clubs and etc. All those things abet on the fact that on the one 
hand it makes students different from other youth groups and on the other hand it forms in them such kind of distinguishing feature as reciprocal help, a kind of "collectivism".

At the same time it should be taken into consideration that in the sphere of free time culture these two generations have preserved valuable attitudes towards family and friends, national and independent peculiarities, as well as traditions of spending leisure and holidays.

\section{REFERENCES}

Bauman, Z. (2002). Individualizirovannoe obshchestvo (Individualized Society, in Russian) (V.L. Inozemtseva Trans.). Moscow: Logos.

Frolov, I.T. (Ed.). (1991).Filosofskii slovar' (Philosophical Dictionary, in Russian). Moscow.

Ikonnikova, S.N. (1985). Sotsiologiya o molodezhi (problemy vospitaniya dukhovnogo oblika) Sociology about Youth (problems of upbringing of spiritual image, in Russian). Leningrad.

Kravchenko, A.I. (2011). Kratkii sotsiologicheski slovar' (Concise Dictionary of Sociology, in Russian). Moscow: Prospekt.

Osipov, G.V., \& Moskvichev, L.N. (Ed.), scient. secret. Chernoshek, O.E. (2008). Sotsiologicheskii slovar' (Sociological Encyclopedic Dictionary, in Russian). Moscova: Norma.

Sokolov, E.V. (1981). Svobodnoe vremya I kul'tura dosuga: filosofsko-sotsiologicheskoe issledovanie (Free Time and the Culture of Leisure: Sociological and Philosophical Research, in Russian). Leningrad.

Surtaev, V.Y. (1998). Sotsiologiya molodezhnogo dosuga (Sociology of Youth Leisure, in Russian). Rostov na/D, St. Petersburg: Hephaestus, St. Petersburg state Academy of Culture.

Tadevosyan, G. (2011). Social-mshakut'ayin gorc'uneut'yun (Socio-Cultural Activity, in Armenian). Yerevan.

Tyurina, E.I. (2012). Tekhnologii sotsial'noi raboty s sem'ei (Technologies of Socio-cultural Work with Families, in Russian), St. Petersburg.: State University of Psychology and Social Work. 